\title{
Design and Implementation of 15-Level Multilevel Cascaded Type Inverter with Reduced Switching Count
}

\author{
V.Tamilselvan, J. C. Vinitha, P. Usha Rani, S. Siva Subramanian
}

\begin{abstract}
In high and medium AC power applications, multilevel inverters (MLI) have significant importance in modern days. The architecture of multi-level cascaded type inverter is preferred because of reduced harmonic distortion, high quality AC output power, least switching loss and minimum switching stress. The existing method uses 8-number of switches to generate 11-level AC voltage. A new design of 15-level multilevel inverter with 6-switching devices is proposed in this paper and DC supply devices are similar to existing method, which outcomes in less switching loss, less complexity of circuit design and less cost. The DC supply for multilevel inverter is taken from solar panel with MPPT technique. The new 6-switch multilevel inverter circuit topology, switching pattern and gate pulse making is explained in this paper. The fast Fourier transform (FFT) analysis of the outputs of 11-level and 15-level of multilevel inverters are related. The new 6-switch 15 level cascaded type inverter circuit has been intended and modeled by using MATLAB software Simulink tool. The simulation outcomes are displayed with less total harmonic distortion and reduced switching loss has been achieved.
\end{abstract}

Keywords: Multilevel Inverter (MLI), Flying clamped capacitor (FCC), T-type inverter, $\pi$-type inverter, T-type inverter, Criss cross $M L I$.

\section{INTRODUCTION}

$\mathrm{N}_{\text {ow a day, a huge number of industrialized applications }}$ have begun to demand high and medium power electronic appliances [1]. On the other hand, power electronic switching devices are undergoing the medium voltage applications haven't created still now. The supply devices for medium power applications are embarrassing to connect directly to the single switch using devices. For that reason, the cascaded type MLI method has been appeared as dissimilar choice for functioning with high power and medium power applications. The MLI technology not simply generates higher voltage levels, other than promotes renewable power generation devices in input side [2].

MLI (Multi level inverter) is one of the electrical power conversion strategies that produce AC type voltage as output side using input DC source [3]. Based on the connection

Revised Manuscript Received on September 27, 2019.

Dr.V.TAMILSELVAN, EEE/ Professor, Karpagam College of Engineering, Coimbatore, India. tami12210@gmail.com

Ms.J.C. VINITHA*, EEE/ Associate Professor, R.M.D Engineering College, Chennai, India. vinithajc.eee@rmd.ac.com

Dr.P.USHA RANI , EEE/Professor, Senior member IEEE, R.M.D Engineering College, Chennai, India. pusharani71@yahoo.com

Dr.S.SIVA SUBRAMANIAN, EEE/Professor, Karpagam College of Engineering, Coimbatore, India. siva.ace@gmail.com methods of switches and supply device, MLI are classified into numerous types. Some of the recent topologies of multilevel inverter are explained in below section.

\section{EMERGING TOPOLOGY OF MLI}

Numerous emerging topologies of MLI have been resent in recent days which using low number of switches to make higher number of output voltage levels. They are $\pi$-type, T-Type, Criss cross type, RV type MLI, Nested type and E-topology MLI etc [4].

\section{A. $\pi$-type MLI}

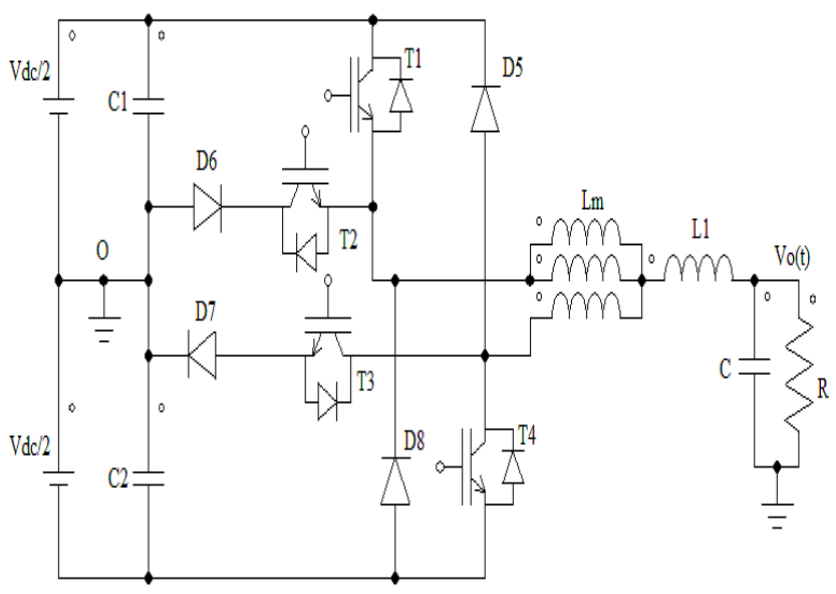

Fig. $1 \pi$-type MLI

A $1 \varphi$, 5-level, three terminal , $\pi$ topology MLI switching circuit is proposed by Yanshen $\mathrm{Hu}$ et al [5], as displayed in figure 1. It has proven to be a perfect option for making more level AC voltage conversion with 2- DC supply. This circuit obtains fewer harmonic and gets higher efficiency. This method offers best loss reduction and decrease the output side LC filter size. Yanshen Hu et. al. examined the current, voltage and switching loss and stress of $1 \varphi, \pi$ topology, 5-voltage level MLI [6] has been analyzed.

\section{B . T topology Inverter}

A $\mathrm{T}$ type three level multilevel inverter has been introduced by M. Schweizer et al [7], which T-type MLI circuit is designed for medium power industrial devices. Figure 2 displays the circuit diagram of T-topology 3-level MLI. This 3-level circuit is the modification of 2- level inverter circuit by connecting a bi-directional switching device in dc link part for best output voltage. This circuit

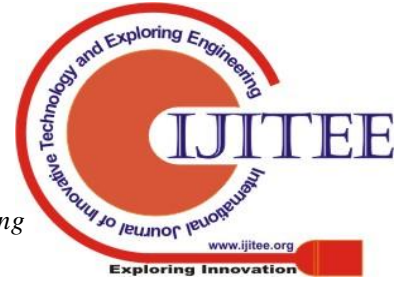


offers better efficiency when switching frequency is low for the reason that low switching loss related to neutral point clamped inverter.

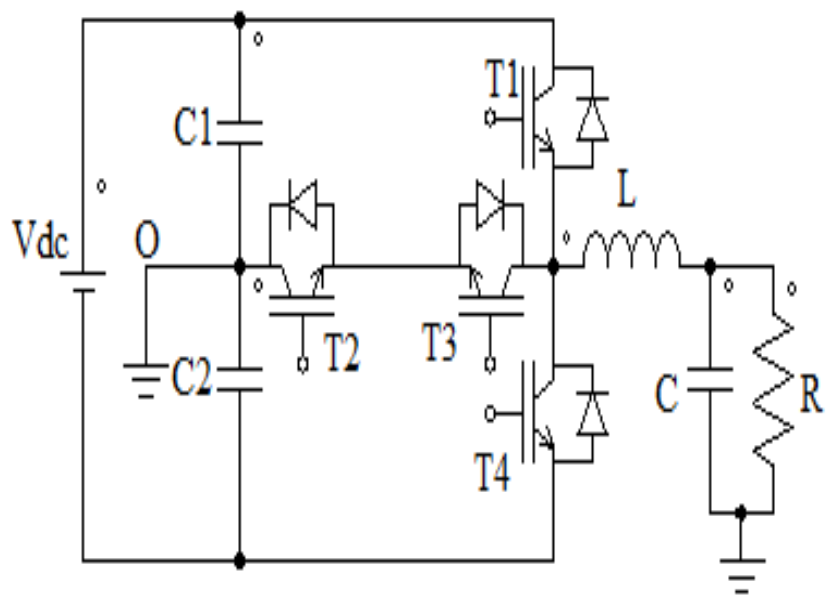

Fig. 2 T topology 3-level MLI

\section{Cross switched Inverter}

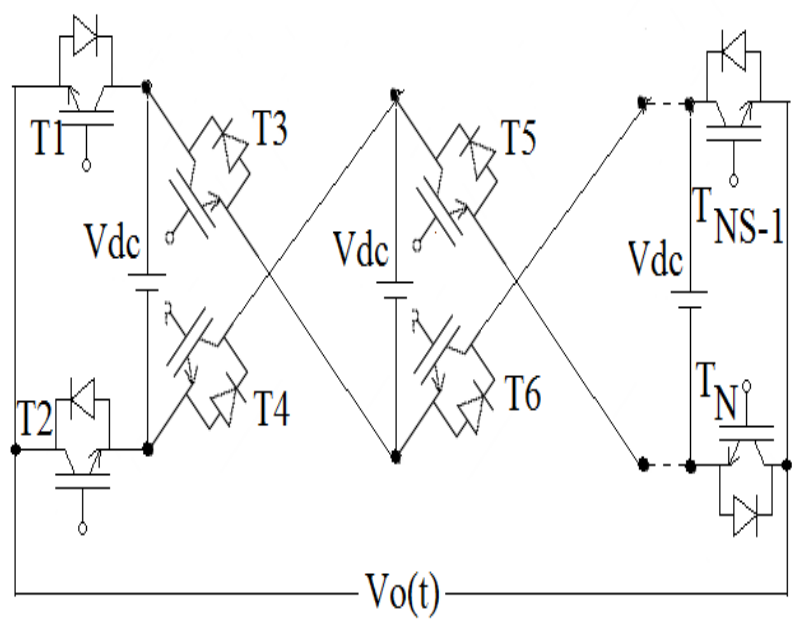

Fig. 3 Cross switched MLI

The cross switched multilevel inverter is introduced by Mahdi Toupchi, which goal as higher voltage levels by low switching device count as displayed in figure 3. Cross type circuit connection is not enhance the switching stress [8].

In this work, a new 15-level multilevel cascaded type inverter with 6-switching device and 3- DC voltage source has been presented. New circuit pattern, gate pulse and switching sequence have been discussed. The working possibility of this new method has been analyzed using MATLAB simulation results.

\section{CONVENTIONAL MULTILEVEL INVERTER}

A. 11-level 6-switch multilevel inverter has been explained in this section. The circuit of conventional 11-level MLI is shown in figure 4. This circuit contains 3-DC supply source, which is connected to the input of multilevel inverter that has capability to make 11-levels with 8 switches. Input voltage sources are selected as the ratio of $1: 2: 2$ to the multilevel inverter. The input DC supply has been given to MLI from solar panel. The output voltage level of MLI is based on the switching sequence.

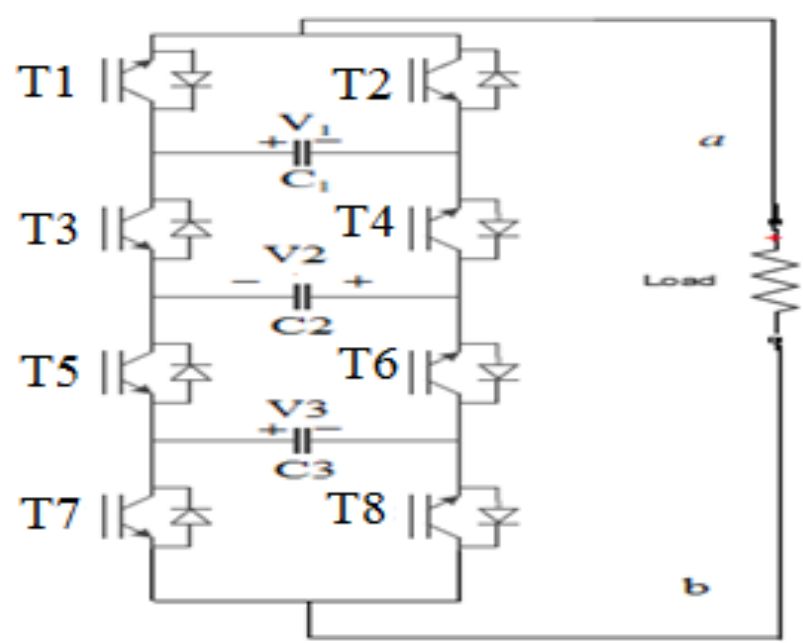

Fig. 4 Conventional multilevel inverter

B. Switching Sequence: The switching sequence used to generate 11-level AC output voltage from 3- DC source and 8 switches has been indicated in table 1 as shown below. The $\mathrm{ON}$ and OFF condition of switch to produce voltage levels in output side is given in table 1 . Here input DC voltage ratio is $1: 2: 2$ i.e, $\mathrm{V} 1=5 \mathrm{~V}, \mathrm{~V} 2=10 \mathrm{~V}$ and $\mathrm{V} 3=10 \mathrm{~V}$. To get $5 \mathrm{~V}$ as output, the switches $\mathrm{S} 1, \mathrm{~S} 4$ and $\mathrm{S} 5$ will be present in turn on condition.

Table 1: 11-level MI Switching state

\begin{tabular}{|c|c|c|c|c|c|c|c|c|c|}
\hline 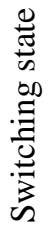 & $\mathrm{T} 1$ & $\mathrm{~T} 2$ & $\mathrm{~T} 3$ & $\mathrm{~T} 4$ & T5 & T6 & $\mathrm{T} 7$ & $\mathrm{~T} 8$ & Vout \\
\hline 1 & 1 & 0 & 0 & 1 & 0 & 1 & 0 & 1 & $\mathrm{~V} 1=5 \mathrm{~V}$ \\
\hline 2 & 0 & 1 & 0 & 1 & 1 & 0 & 1 & 0 & $\mathrm{~V} 2=10 \mathrm{~V}$ \\
\hline 3 & 1 & 0 & 0 & 1 & 1 & 0 & 1 & 0 & $\mathrm{~V} 1+\mathrm{V} 2=15 \mathrm{~V}$ \\
\hline 4 & 0 & 1 & 0 & 1 & 1 & 0 & 0 & 1 & $\mathrm{~V} 2+\mathrm{V} 3=20 \mathrm{~V}$ \\
\hline 5 & 1 & 0 & 0 & 1 & 1 & 0 & 0 & 1 & $\begin{array}{l}\mathrm{V}+\mathrm{V} 2+\mathrm{V} 3= \\
25 \mathrm{~V}\end{array}$ \\
\hline 6 & 0 & 0 & 0 & 0 & 0 & 0 & 0 & 0 & 0 \\
\hline 7 & 0 & 1 & 1 & 0 & 1 & 0 & 1 & 0 & $-\mathrm{V} 1=-5 \mathrm{~V}$ \\
\hline 8 & 1 & 0 & 1 & 0 & 0 & 1 & 0 & 1 & $-\mathrm{V} 2=-10 \mathrm{~V}$ \\
\hline 9 & 0 & 1 & 1 & 0 & 0 & 1 & 0 & 1 & $-\mathrm{V} 1-\mathrm{V} 2=-15 \mathrm{~V}$ \\
\hline 10 & 1 & 0 & 1 & 0 & 0 & 1 & 1 & 0 & $-\mathrm{V} 2-\mathrm{V} 3=-20 \mathrm{~V}$ \\
\hline 11 & 0 & 1 & 1 & 0 & 0 & 1 & 1 & 0 & $\begin{array}{l}-\mathrm{V} 1-\mathrm{V} 2-\mathrm{V} 3=- \\
25 \mathrm{~V}\end{array}$ \\
\hline
\end{tabular}

The switching sequence table clearly shows the three input voltage source has been used to produce 11-level AC output voltage with less total harmonic distortion.

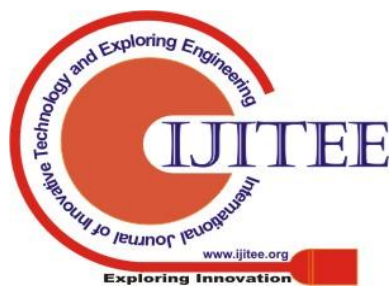




\section{NEW 15-LEVEL 6-SWITCH MLI}

The new 15-level MLI circuit contains 6-switching devices and 3-DC supply source. The conventional 11- level multilevel inverter used 8-switches and 3-DC source. Compared to conventional technique, the proposed technique generates 4-more levels by using 6-switches. Figure 5 shows the block diagram of proposed 15-level MLI.

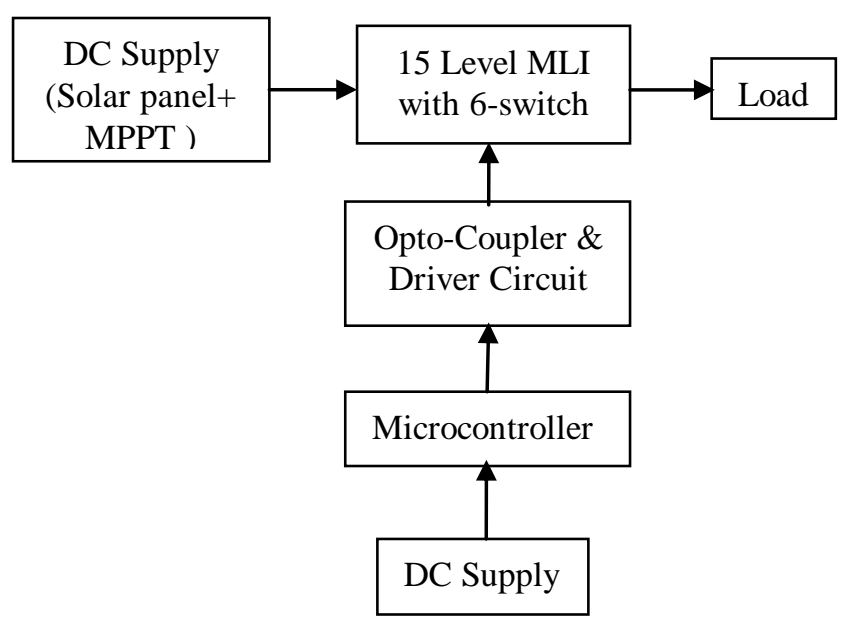

Fig. 5 Proposed block diagram

The components present in this proposed method are solar panel, 15-level multilevel inverter, AC load, microcontroller, opto-coupler and driver circuit. Each and every unit is explained in below sections.

\section{a. SOLAR CELL AND PANEL MODELLING}

Design and modeling of photovoltaic cell and panel can be derived by many methods in software like PSPICE \& MATLAB etc. There are numerous schemes to symbolize a model as like Physical modeling, Mathematical modeling and Embedded Programming [10].

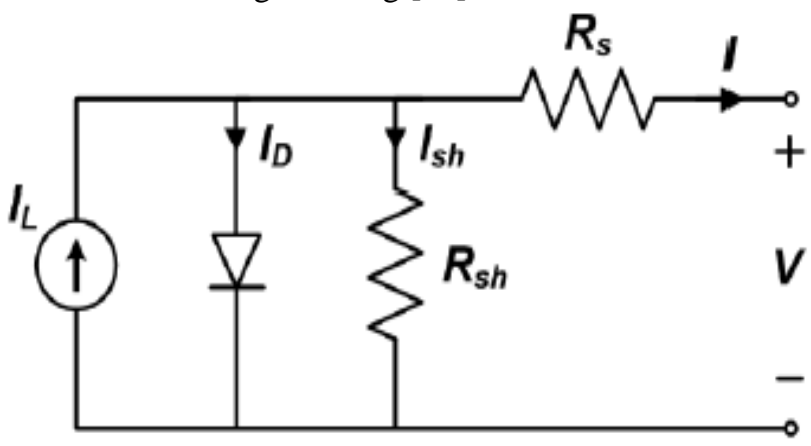

Fig. 6 Electrical equivalent of photovoltaic cell

Electrical equivalent circuit of single photovoltaic cell is displayed in figure 6 . In the circuit diagram Rs indicates series resistance of $\mathrm{P}-\mathrm{N}$ junction of solar cell and Rsh indicates shunt resistance. The voltage-current characteristics of solar cell depend upon series resistor [11]. $I_{d}$ is current flows through diode and Ish is shunt leakage current. The output current I is calculated by applying KCL in equivalent circuit:

$$
\mathrm{I}=\mathrm{I}_{\mathrm{ph}}-\left(\mathrm{I}_{\mathrm{d}}+\mathrm{I}_{\mathrm{sh}}\right)
$$

From the equivalent circuit, output current is the sum of diode current and shunt resisitor current [12]. Hence the simplified equation is

$$
\mathrm{I}=\mathrm{I}_{\mathrm{ph}}-\mathrm{I}_{0}
$$

Photon current $\left(\mathrm{I}_{\mathrm{ph}}\right)$ is produced on incorporation of solar irradiation by hotovoltaic cell therefore photocurrent $\left(\mathrm{I}_{\mathrm{ph}}\right)$ value is directly linked to deviation in solar temperature and irradiance that is [13]:

$$
\mathrm{I}_{\mathrm{ph}}=\left(\mathrm{I}_{\mathrm{scr}}+\mathrm{k}_{\mathrm{i}} \Delta \mathrm{T}\right) \frac{\mathrm{G}}{\mathrm{Gr}}
$$

The photovoltaic cell reverse saturation current (Irs) will be determined by [14]:

$$
\mathrm{I}_{\mathrm{o}}=\mathrm{I}_{\mathrm{rS}}\left(\frac{T}{T_{\text {ref }}}\right)^{3} \exp \left[\left(\frac{\mathrm{q} \mathrm{Ego}_{\mathrm{g}}}{\mathrm{A} \mathrm{K}}\right)\left(\frac{\Delta \mathrm{T}}{\mathrm{T}_{\text {ref }} \mathrm{T}}\right)\right]
$$

Where, Irs - reverse saturation current.

Ego - band-gap energy of pn junction material.

The current values of Io and Iph will derived the value of current I as follows [15]:

$I_{p v}=I_{p h}-I_{0}\left[\exp \left(\frac{q\left(V_{p v}+I_{p v} R s\right)}{A K T}\right)-1\right]-\frac{\left(V_{p v}+I_{p v} R s\right)}{R p}$

The power output is exaggerated by weather constraint variations that are shading and temperature [16]. If temperature rises above insignificant value then voltage loss varies from 0.022 to $0.056 \mathrm{~V} /{ }^{\circ}$. V-I and $\mathrm{P}-\mathrm{V}$ waveform for dissimilar temperature and irradiance are shown in figure 7.

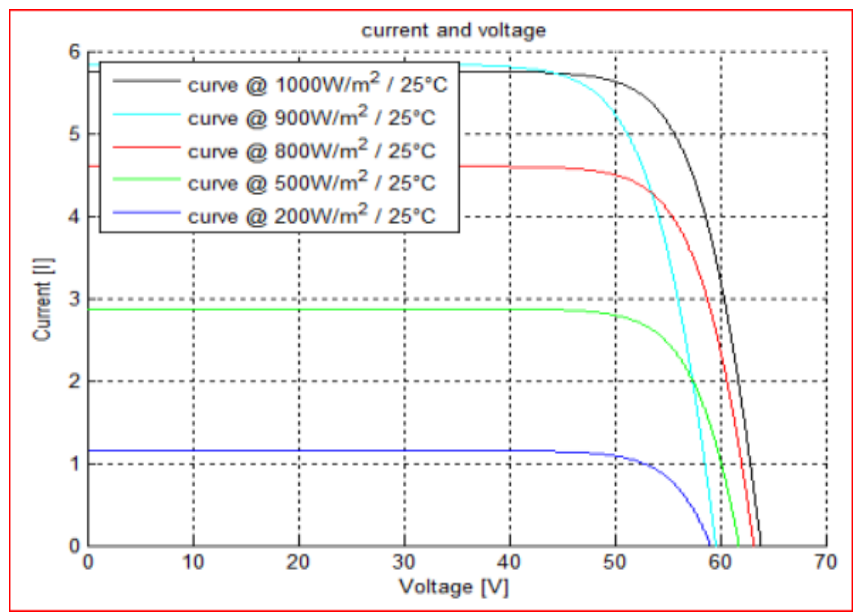

Fig. 7 Voltage and current curve for PV cell with different temperature and intensity

TABLE 2: SOLAR MODULE PARAMETER

\begin{tabular}{|c|c|c|}
\hline VARIABLE & PARAMETER & VALUE \\
\hline PV & Model & $\begin{array}{c}\text { F-MSN-75W- } \\
\text { R-02 }\end{array}$ \\
\hline Pmax & Maximum output power & $75 \mathrm{~W}$ \\
\hline Vin & Open circuit voltage & $21.7 \mathrm{~V}$ \\
\hline Isc & Short circuit current & $5.0 \mathrm{~A}$ \\
\hline
\end{tabular}




\section{Design and Implementation of 15-Level Multilevel Cascaded Type Inverter with Reduced Switching Count}

\section{b. MPPT BY P\&O TECHNIQUE}

Power generation of solar panel depends upon climatic condition such as temperature and radiation. MPPT (Maximum Power Point Tracking) method is a technique used to regulate output DC voltage of solar panel. Perturb and observation algorithm is used to MPPT technique. Figure 8 displays flow chart of $\mathrm{P} \& \mathrm{O}$. This algorithm senses the input voltage and current from photovoltaic panel using voltage and current sensors.

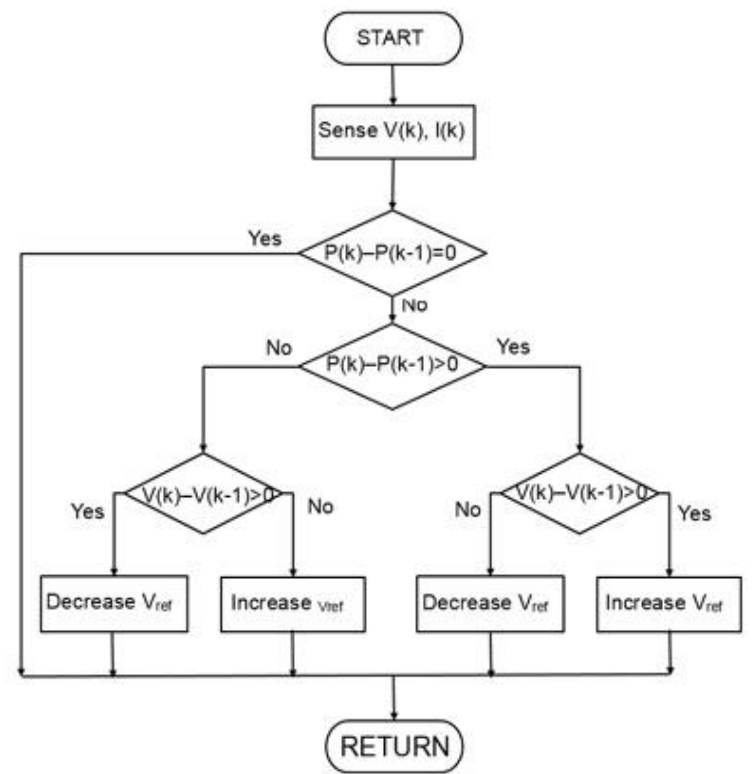

Fig. 8 Flowchart for $\mathrm{P} \& \mathrm{O}$ algorithm

\section{PROPOSED 15-LEVEL MLI}

The proposed multilevel inverter produced 15-output AC voltage levels without using capacitors and bidirectional switches. It contains 6 number of controlled switching devices (S1, S2, S3, S4, S5 and S6) and one diode (D) connected in between three supply DC sources $(\mathrm{Vdc} 1, \mathrm{Vdc} 2$ and Vdc3) as shown in figure 9.

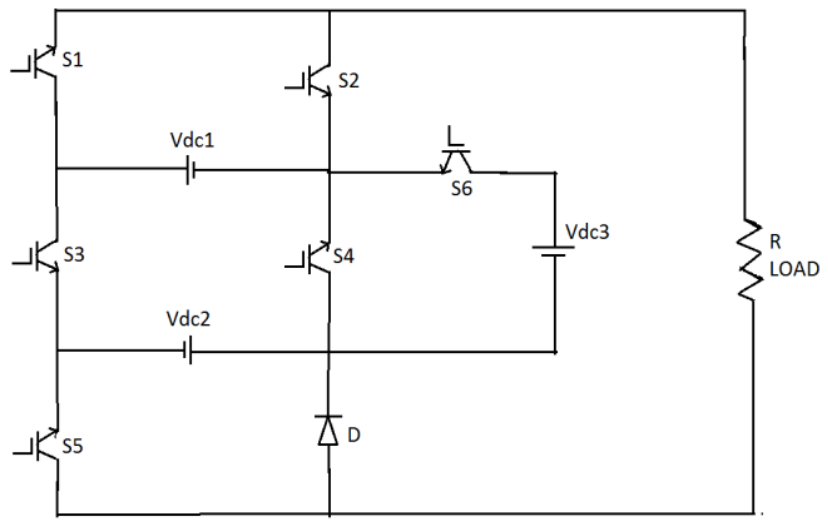

Fig. 9 Proposed circuit diagram

The supply devices Vdc1, Vdc2 and Vdc3 are give voltage to the load in the proportion of 1:2:4 respectively. Here, $\mathrm{Vdc} 1=5 \mathrm{~V}, \mathrm{Vdc} 2=10 \mathrm{Vand} \mathrm{Vdc} 3=20 \mathrm{~V}$ is used. The voltage sources are connected or disconnected to load depend upon the ON and OFF condition of switches S1-S6, hence the alternating 15-level voltage appear across the load. The modes of operation of making all levels of AC output voltage is explained in below section.

\section{d. MODES OF OPERATION}

All current flow paths of all modes of operation is explained in this section.

Mode $1(\mathrm{Vo}=\mathrm{Vdc} 1=5 \mathrm{~V})$ :

In this mode of operation, the voltage source $\mathrm{Vdc} 1$ is connected to load through the source Vdc1- S1- R load- D $\mathrm{S} 4-\mathrm{Vdc} 1$. Hence $\mathrm{Vdc1}=5 \mathrm{v}$ is appear across the load. This current flow direction is shown in figure 10.

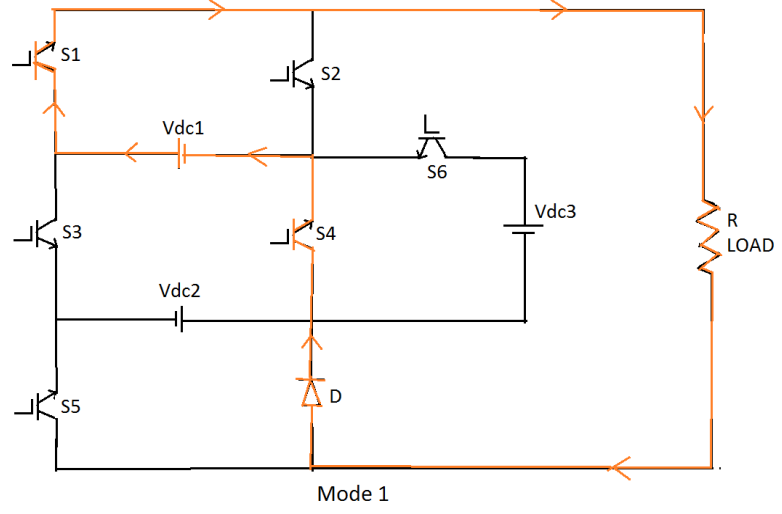

Fig.10. Mode 1 operation

Mode 2 \& $3\left(\mathrm{Vo}=\mathrm{Vdc} 2 \& \mathrm{~V}_{\mathrm{o}}=\mathrm{Vdc} 1+\mathrm{Vdc} 2\right)$ :

In mode 2 operation, the voltage source $\mathrm{Vdc} 2=10 \mathrm{~V}$ appear across the load. The current flow path in this mode of operation is $\mathrm{Vdc} 2-\mathrm{S} 4-\mathrm{S} 2-\mathrm{R}$ load $-\mathrm{D}-\mathrm{Vdc} 2$, as shown in figure 11 .

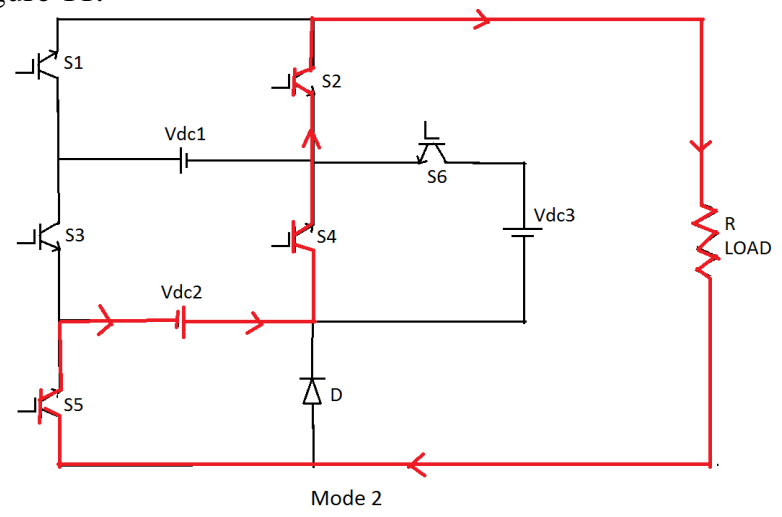

Fig. 11 mode 2 operation

Figure 12 shows the current flow path of $3^{\text {rd }}$ mode operation. The circuit will close through source Vdc1+ Vdc $2=15 \mathrm{~V}$. the circuit is closed through Vdc1 $-\mathrm{S} 4-\mathrm{Vdc} 2-\mathrm{S} 1-$ R load - S5 - Vdc1.

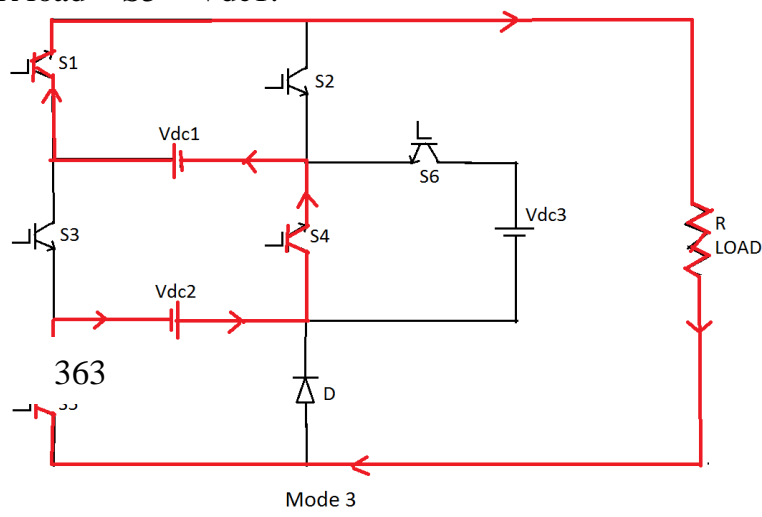

Fig. 12 mode 3 operation 
Mode 4 \& $5(\mathrm{Vo}=\mathrm{Vdc} 3 \& \mathrm{Vo}=\mathrm{Vdc} 1+\mathrm{Vdc} 3)$ :

In mode 4 operation, the voltage source $\mathrm{Vdc} 3=20 \mathrm{~V}$ appear across the load. The current flow path in this mode of operation is $\mathrm{Vdc} 3-\mathrm{S} 6-\mathrm{S} 2-\mathrm{R}$ load $-\mathrm{D}-\mathrm{Vdc} 3$, as shown in figure 13 .

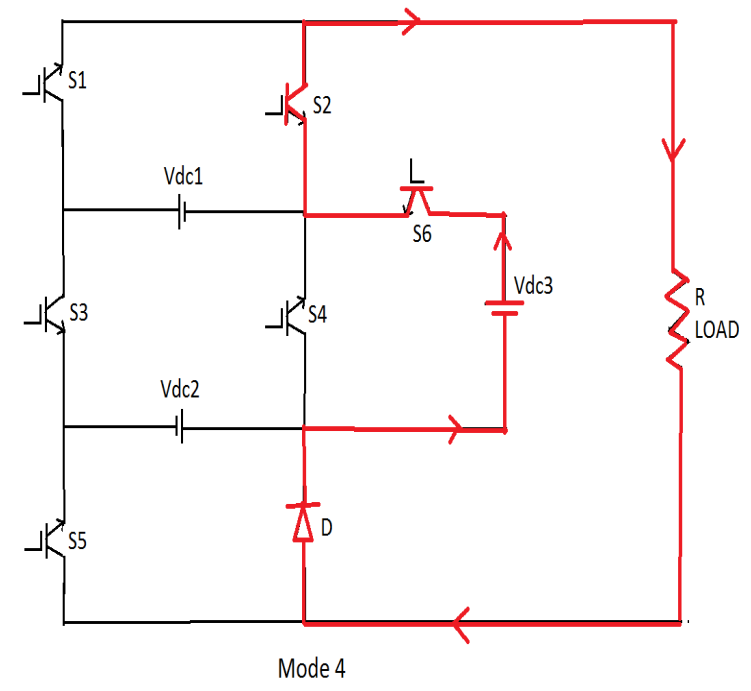

Fig. 13 mode 4 operation

In mode 5 operation, the voltage source $\mathrm{Vdc} 3+\mathrm{Vdc} 1=25 \mathrm{~V}$ appear across the load. The current flow path in this mode of operation is Vdc3 - S6 - Vdc1- S1 - R load - D - Vdc3, as shown in figure 14.

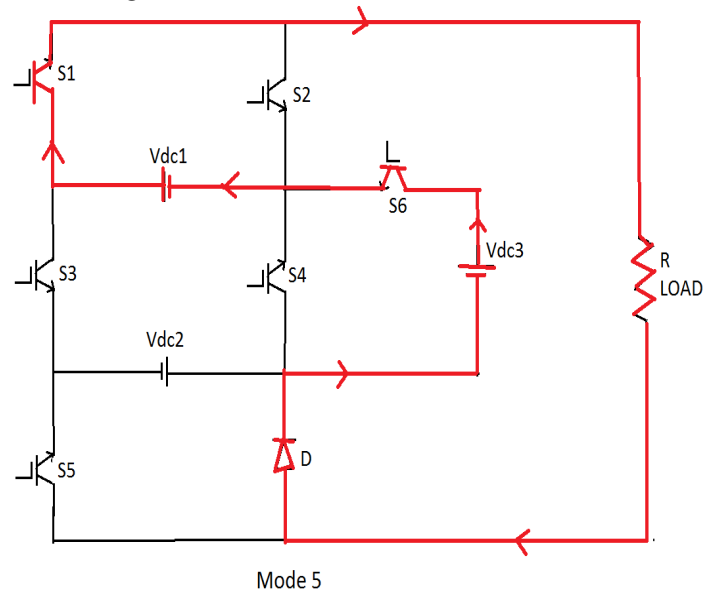

Fig. 14 mode 5 operation

Mode 6 \& $7\left(\mathrm{Vo}_{\mathrm{o}}=\mathrm{Vdc} 2+\mathrm{Vdc} 3 \& \mathrm{Vo}=\mathrm{Vdc} 1+\mathrm{Vdc} 2+\mathrm{Vdc} 3\right)$ : In mode 6 operation, the voltage source $\mathrm{Vdc} 2+\mathrm{Vdc} 3=30 \mathrm{~V}$ appear across the load.

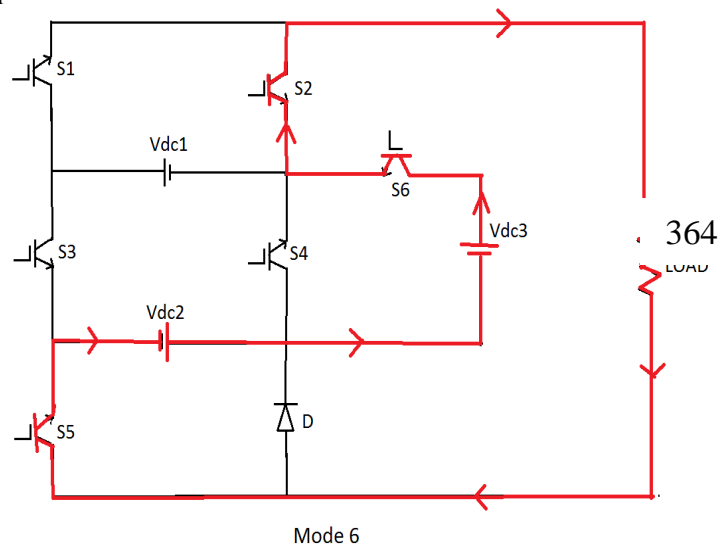

Fig. 15 mode 6 operation
The current flow path in this mode of operation is Vdc2 $\mathrm{Vdc} 3-\mathrm{S} 6-\mathrm{S} 2-\mathrm{R}$ load $-\mathrm{S} 5-\mathrm{Vdc} 2$, as shown in figure 15

In mode 7 operation, the voltage source $\mathrm{Vdc} 1+\mathrm{Vdc} 2+\mathrm{Vdc} 3=35 \mathrm{~V}$ appear across the load. The current flow path in this mode of operation isVdc2 - Vdc3 - S6 $\mathrm{Vdc} 1-\mathrm{S} 1-\mathrm{R}$ load $-\mathrm{S} 5$ - Vdc2, as shown in figure 16.

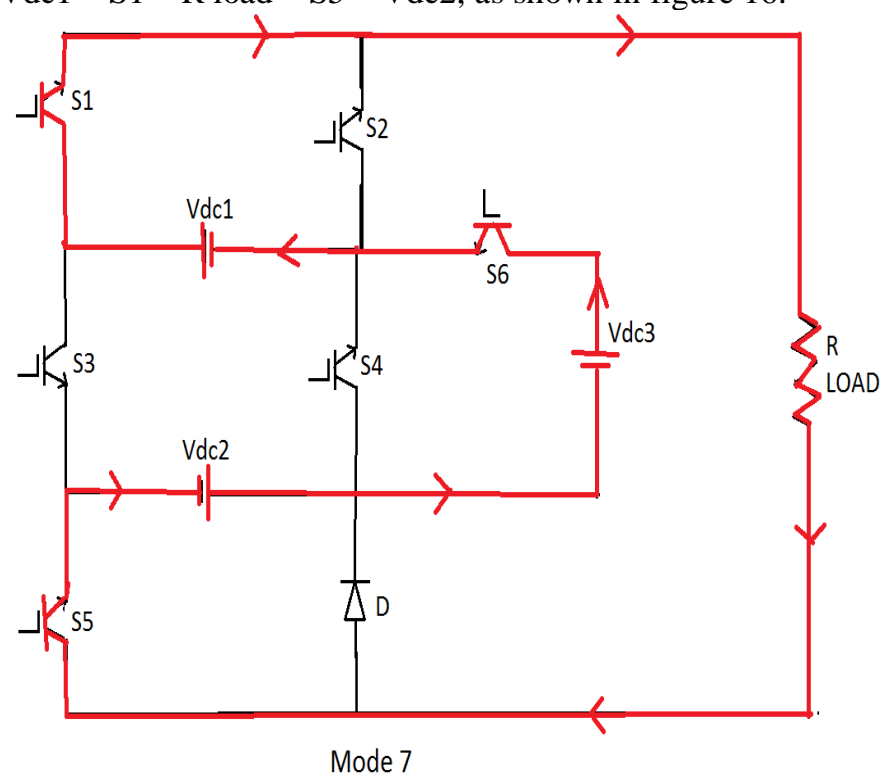

Fig.16 mode 7 operation

Mode $8(\mathrm{Vo}=0 \mathrm{~V})$

In this mode of operation all switching devices are turn off condition to generate $0 \mathrm{~V}$ as output across load.

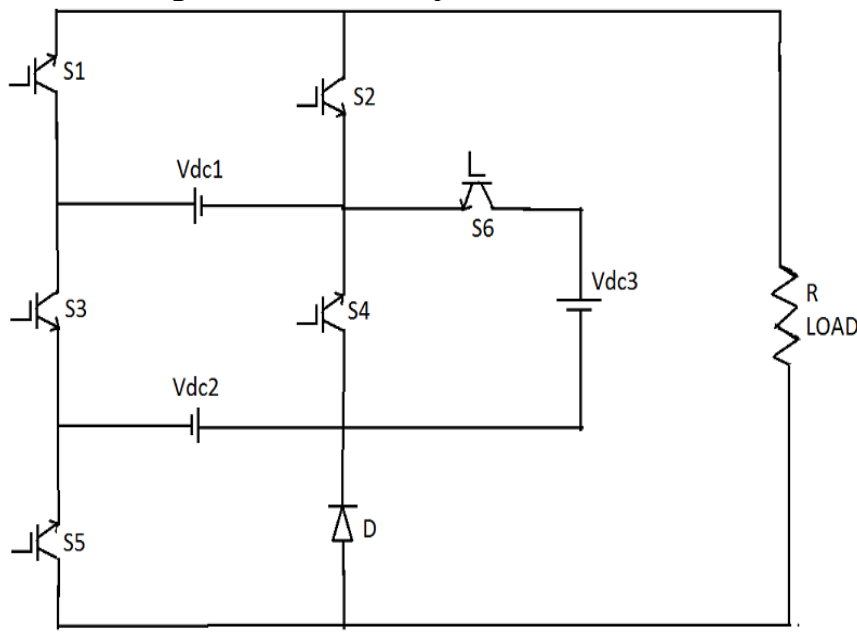

Mode 8

Figure 17. Mode 8 operation

The above modes of operation are written as table for easy understanding as shown in below switching state table 3 . This table contains the On and OFF state switches to make each and every level of output voltage. 


\begin{tabular}{|c|c|c|c|c|c|c|c|}
\hline 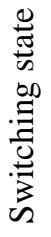 & S1 & $\mathrm{S} 2$ & S3 & S4 & S5 & S6 & Vo \\
\hline 1 & 1 & 0 & 0 & 1 & 0 & 0 & Vdc1 \\
\hline 2 & 0 & 1 & 0 & 1 & 1 & 0 & $\mathrm{Vdc} 2$ \\
\hline 3 & 1 & 0 & 0 & 1 & 1 & 0 & $\mathrm{Vdc} 1+\mathrm{Vdc} 2$ \\
\hline 4 & 0 & 1 & 0 & 0 & 0 & 1 & Vdc3 \\
\hline 5 & 1 & 0 & 0 & 0 & 0 & 1 & $\mathrm{Vdc} 3+\mathrm{Vdc} 1$ \\
\hline 6 & 0 & 1 & 0 & 0 & 1 & 1 & $\mathrm{Vdc} 3+\mathrm{Vdc} 2$ \\
\hline 7 & 1 & 0 & 0 & 0 & 1 & 1 & $\mathrm{Vdc} 3+\mathrm{Vdc} 2+\mathrm{Vdc} 1$ \\
\hline 8 & 0 & 0 & 0 & 0 & 0 & 0 & 0 \\
\hline
\end{tabular}

Table 3: Switching State Table

\section{SIMULATION RESULT:}

The working of new15-level circuit is analyzed by MATLAB software. Simulation circuit, gate pulse, output voltage, output current and THD waveforms are explained in this section.

\section{SIMULATION CIRCUIT DIAGRAM OF PROPOSED MLI:}

Figure.18 demonstrates the 15-level MLI circuit diagram drawn in MATLAB Simulink software. Gate pulses are given to all controlled switching devices and resistive load is used to measure AC output voltage. Voltage and current measurement blocks are used to display output AC voltage and current. FFT analysis block is present in MATLAB to measure THD present in AC voltage.

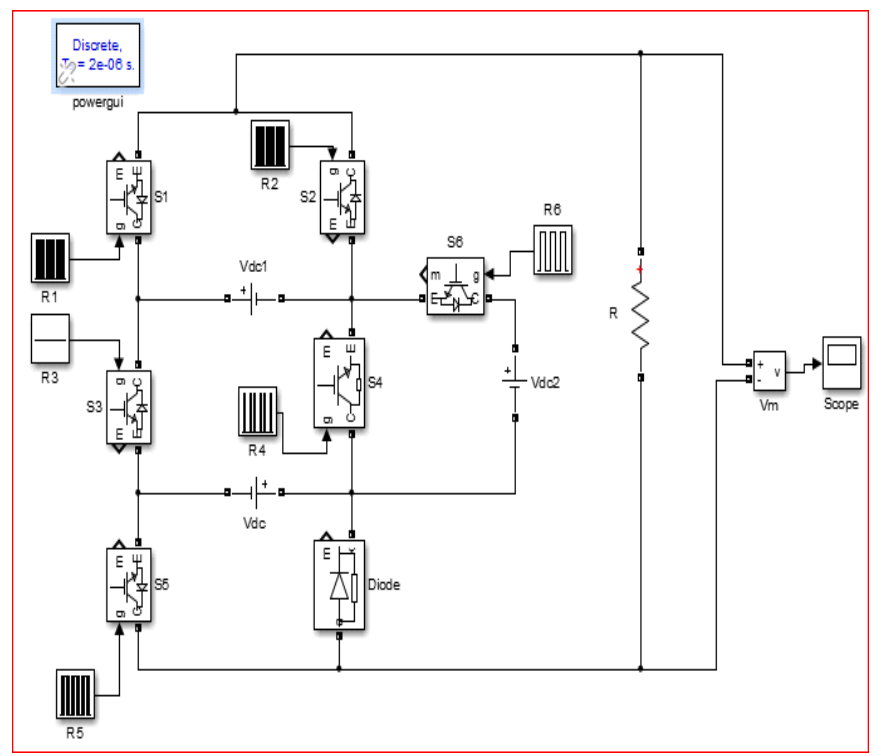

Fig. 18 Simulation circuit diagram
GATE PULSE:

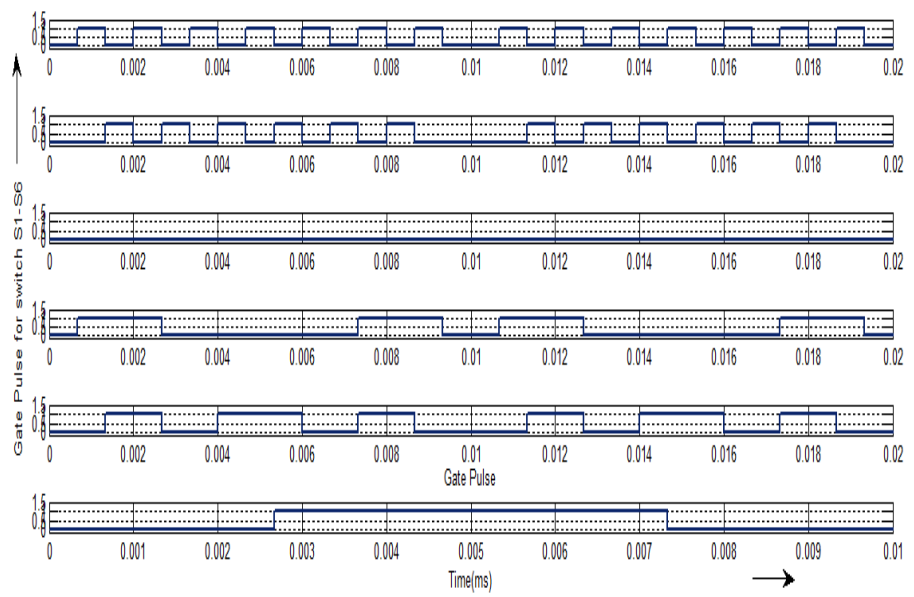

Fig. 19 Gate pulse given to switch S1 - S6

This proposed 15-level multilevel inverter contains 6 numbers of controlled switching devices (S1-S6). The amplitude of AC output depends upon $\mathrm{ON}$ and $\mathrm{OFF}$ condition of six switches. This gate pulses are generated based on switching sequence table. Figure 19 shows the gate pulse for S1-S6 switches.

\section{OUTPUT VOLTAGE WAVEFORM}

The number of levels produced across load has been demonstrated in figure 20. The amplitude of supply DC sources are $\mathrm{Vdc} 1=5 \mathrm{~V}, \mathrm{Vdc} 2=10 \mathrm{~V}$ and $\mathrm{Vdc} 3=20 \mathrm{~V}$. Hence the amplitude of AC output voltage is $32.5 \mathrm{~V}$; remaining voltage is dropped across switching devices. The frequency of $\mathrm{AC}$ output voltage is $50 \mathrm{~Hz}$. The magnitude of AC voltage has been varied based on the proportion of supply side DC source.

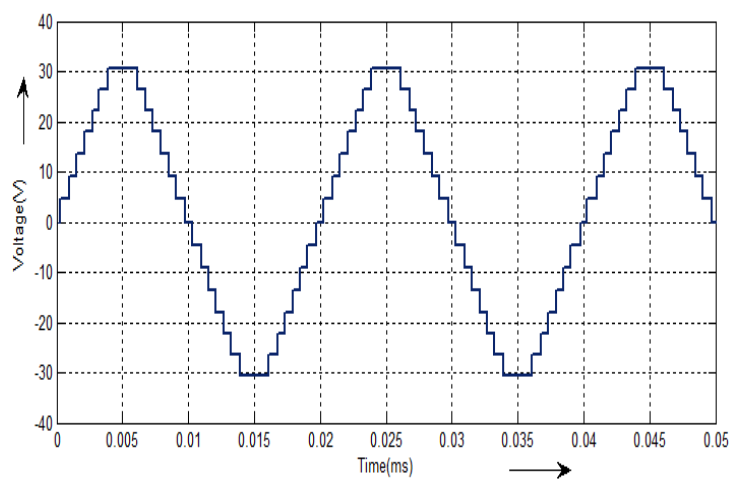

Figure 20. Output voltage and current

\section{OPTOCOUPLER AND DRIVER CIRCUIT:}

Most recent optocoupler strategies use a phototransistor as their input side; such device is commonly known as an 'optocoupler', because the input side LED and the output terminal phototransistor are optically attached. Figure $\mathbf{2 1}$ displays the basic structure of an optocoupler, together with $18 \mathrm{~V}$ driver circuit. 


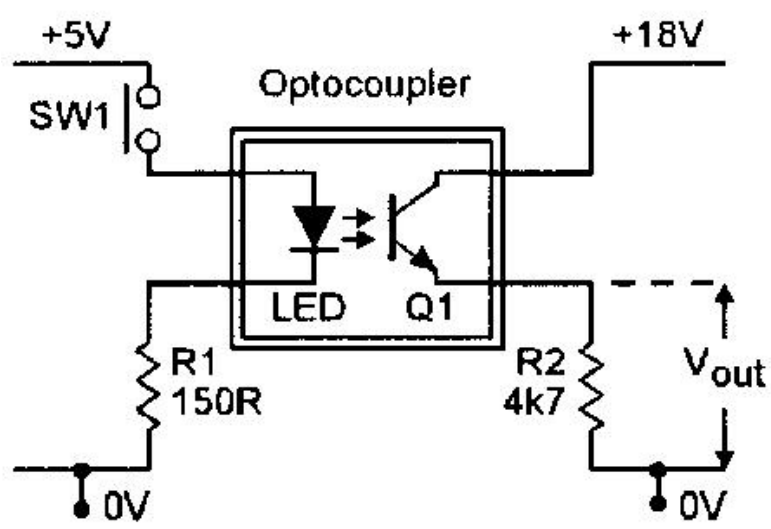

Fig. 21 Optocoupler and driver circuit

When SW1 switch is in open condition, no current will flows through the LED, hence no light fall on the phototransistor Q1; Q1 transmits virtually 0 collector terminal current under this situation, therefore 0 voltage is present across output terminal resistor $\mathrm{R} 2$. On the other hand, when switch SW1 is closed, current will flows to R1 resistor through the LED, and the resultant light falls on phototransistor Q1, therefore collector voltage (18V) will across $\mathrm{R} 2$ resistor (Vout). In this circuit, the output terminal current is regulated by its input terminal current, that a regulator circuit coupled to its input terminal can be isolated electrically from the entire output circuit. This 'isolating' property is the key attraction of this kind of optocoupler, which is commonly called as an isolating- optocoupler.

\section{MICROCONTROLLER:}

Microcontroller is used to generate gate pulse for controlled switching devices. In this proposed circuit, 6 controlled switches are used. So we need to generate 6 gate pulses. The Delfino Micro controller series of C2000 real time Controller is leading floating point presentation and analog combination to regulate applications. The Delfino microcontrollers have simplified development and offer world class dispensation for demanding, real time application. The main feature of this dual core microcontroller is operating at $200 \mathrm{MHz}$ on each central processing unit and single core processors operat $300 \mathrm{MHz}$. The pulse generation using this proce 366 e very easy. These microcontrollers are directly interface to matlab software for generate gate pulse.

\section{I.THD (HARMONIC DISTORTION):}

THD is a computation of nearness value to waveform which is attain to the outline of the fundamental frequency waveform. It can be determined by using following equation

$$
T H D=\frac{1}{V_{1}} \sqrt{\sum_{n=2,3}^{\infty} V n^{2}}
$$

Where, $\mathrm{V}_{1}$-Voltage with fundamental frequency and $\mathrm{V}_{\mathrm{n}}$-Voltage of $\mathrm{n}^{\text {th }}$ order frequency wave.

THD ANALYSIS OF SINGE LEVEL AC OUTPUT VOLTAGE:
THD analysis of one-level AC voltage obtained from single $\mathrm{H}$-bridge MLI is illustrated in figure 22. This single level AC output voltage is generated by using single DC source and 4 switching devices. The THD value present in

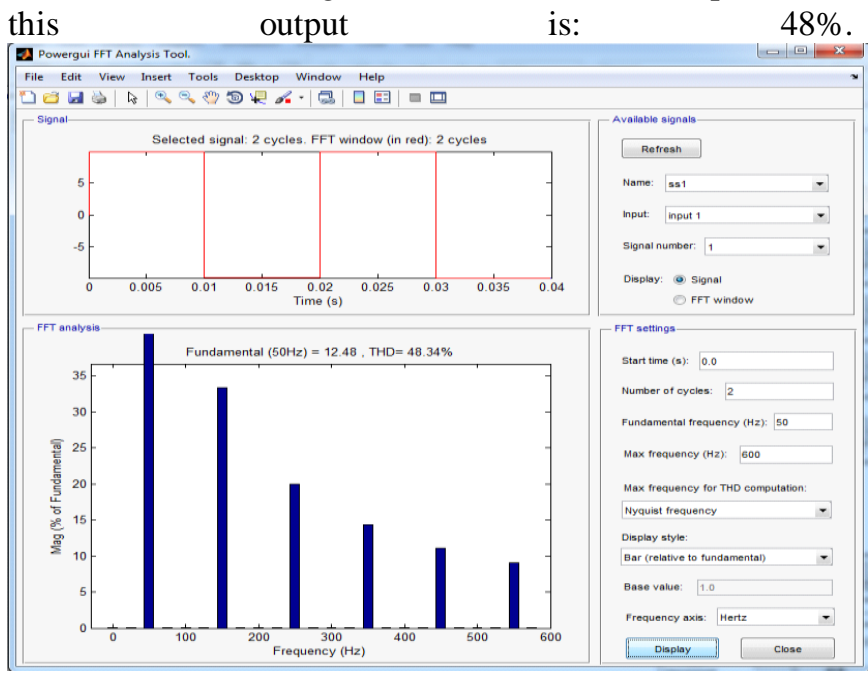

Figure 22: THD analysis of single level AC voltage

THD ANALYSIS OF CONVENTIONAL 11-LEVEL MLI:

The THD analysis of conventional 11-level multilevel inerter with 8 -switching device is shown in figure 23 . The total harmonic distortion resent in this waveform is around $9 \%$.

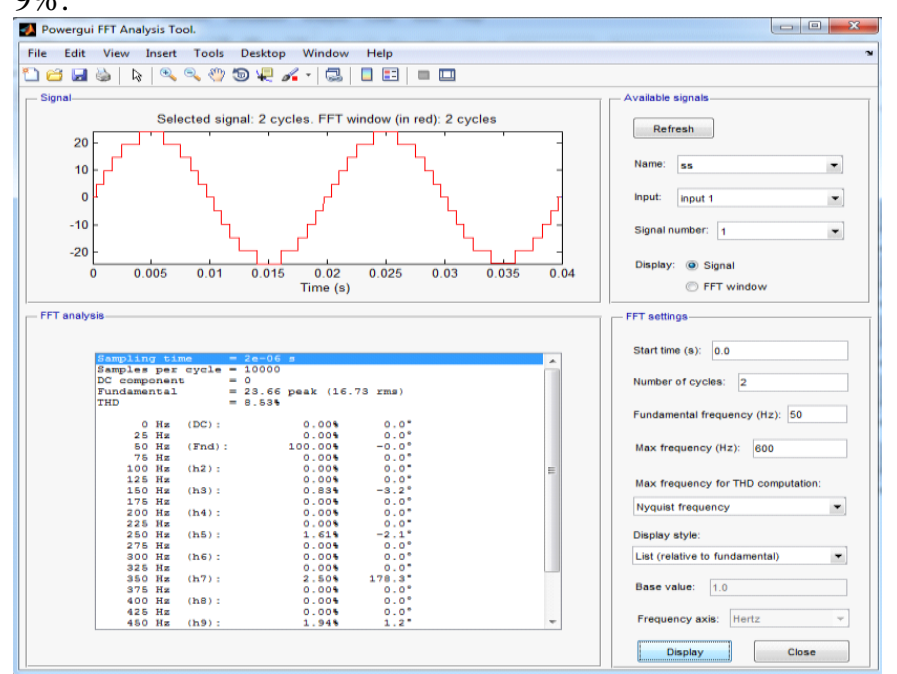

Figure 23: THD analysis of 11-level MLI

In figure the $\mathrm{AC}$ voltage is taken as input parameter for FFT analysis is done using the given sampling time, samples per second etc through which total harmonic distortion can be calculated.

\section{THD ANALYSIS OF PROPOSED 15-LEVEL MLI:}

Using MATLAB Simulink software FFT analysis is done by using nyquist frequency to find THD value, which is displayed by either bar chart or list of values. 


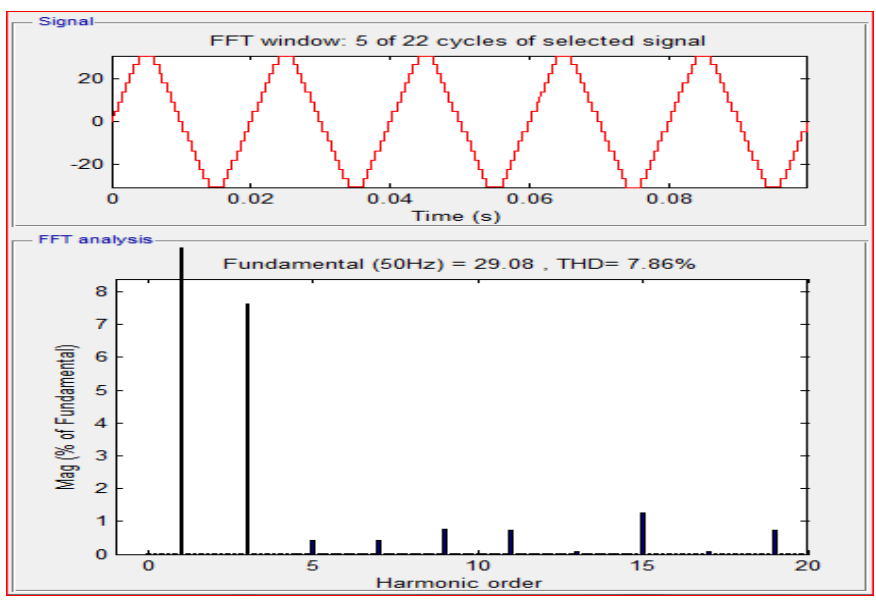

Fig. 24 THD analysis of proposed 15-level MLI

The THD value present in 15 -level MLI is : $7.86 \%$ using FFT analysis method in MATLAB software as shown in figure 24 .

\section{COMPARISION}

The THD value assessment of various AC voltage levels has been displayed in table 3 .

\begin{tabular}{|c|c|c|c|}
\hline S1.No & $\begin{array}{c}\text { Output voltage } \\
\text { Level }\end{array}$ & $\begin{array}{c}\text { Number of switches } \\
\text { used }\end{array}$ & $\begin{array}{c}\text { THD } \\
\%\end{array}$ \\
\hline 1 & 1 level & 4 & 48.34 \\
\hline 2 & 7 -level & 6 & 12 \\
\hline 3 & 11 -level & 8 & 8.53 \\
\hline 4 & 15 -level & 6 & 7.86 \\
\hline
\end{tabular}

From this table, total harmonic distortion is reduced, when the voltage levels are increased. The switching count of proposed method is low compared to conventional techniques.

\section{CONCLUSION}

Thus a new 15-level single phase AC voltage topology has been proposed with 6 power semiconductor switching device, less THD and low conduction loss and switching stress and loss. In consequence of using less switching devices, automatically reduce the circuit complexity, size and cost, which automatically decrease the conduction and switching and losses. The main advantage of this proposed method rather than existing scheme is huge drop of THD. The circuit configuration of proposed method is simple hence the gate pulse making and control strategy also very simple. The harmonic distortion of proposed 15-level AC output voltage has been reduced around $2 \%$ when compared to conventional 11-level AC output voltage method. These results are obtained from the simulation of MATLAB simulink software.

\section{REFERENCES}

1. J. Rodriguez, J.S. Lai and F.Z. Peng, "Multilevel inverters: survey of topologies, controls, and applications," IEEE Trans Ind. Appl., vol. 49-4, pp. 724-738, Aug. 2002.

2. E. Babaei and S.H. Hosseini, "New cascaded multilevel inverter topology with minimum number of switches," Energy Conversion and Management, vol. 50, pp. 2761-2767, 2009.

3. Hulusi Karaca, "A Novel Topology for Multilevel Inverter with Reduced Number of Switches", Proceedings of the World Congress on Engineering and Computer Science, Vol 1, 2013.

4. R. Santhi1, K. Giridharan and A. Kannabhiran, "A Survey on Voltage Source Multi Level Inverter Topology”, IEEE International Conference on Power, Control, Signals and Instrumentation Engineering, pp.1262-1271, 2017.

5. Yanshen Hu, Yunxiang Xie, Dianbo Fu, and Li Cheng, "A New Single-Phase $\pi$-Type 5-Level Inverter Using 3-Terminal Switch-Network", IEEE Transactions On Industrial Electronics, Nov-16.

6. G.Ceglia V.Guzman, C. C.Sanchez,F.Ibanez ,J. Walter, and M.I.Gimenez, "A new simplified multilevel inverter topology for DC-AC conversion," IEEETrans.PowerElectron., vol.21, no.5, pp.1311- 1319, Sep.2006.

7. Mahdi Toupchi Khosroshahi "Crisscross cascade multilevel inverter with reduction in number of components", IET Power Electronics, April 2014.

8. Mostafa Abarzadeh , Hossein Madadi Kojabadi Liuchen Chang, "A Modified Static Ground Power Unit Based on Novel Modular Active Neutral Point Clamped Converter", IEEE Transactions on Industry Applications, 2016.

9. Abdul Halima Mohamed Yatim, and Ehsan Najafi, Design and Implementation of a New Multilevel Inverter Topology IEEE transactions on industrial electronics, vol. 59, no. 11, November 2012

10. José Carlos de Oliveira Custódio, Cícero da Rocha Souto, Priscilla K. Pontes de Melo, Adriano N. Ramos, "Illuminance Sencor for error correction of DC-DC converter tracking using perturb and observe algorithm", IEEE International Instrumentation and Measurement Technology Conference, 2015.

11. Samer Alsadi, Basim Alsayid, "Maximum Power Point Tracking Simulation For Photovoltaic Systems Using Perturb And Observe Algorithm", International Journal of Engineering and Innovative Technology, Vol 2, Issue 6, 2012.

12. Ravi Prakash, Sandeep Singh, "Designing and Modelling of Solar Photovoltaic Cell and Array", IOSR Journal of Electrical and Electronics Engineering, Vol.11, issue.2,pp.35-40,2016.

13. Gurcharan Singh and Vijay Kumar Garg, "THD Analysis of Cascaded H-Bridge Multi-Level Inverter", IEEE International Conference on Signal Processing, computing and control, pp.229- 234, 2017.

14. Ebrahim Babaei, Mohammad Farhadi Kangarlu, Mehran Sabahi "Extended multilevel converters :an attempt to reduce the number of independent DC voltage sources in cascaded multilevel converters " IET Power Electronics,July2013.

15. Mohamad Reza Banaei, Mohammad Reza Jannati Oskuee, Hossein Khounjahan., "Reconfiguration of semi-cascaded multilevel inverter to improve systems performance parameters" IET Power Electronics,September 2013.

16. Sébastien Mariéthoz, "Design and Control of High-Performance Modular Hybrid Asymmetrical Cascade Multilevel Inverters", IEEE Transactions On Industry Applications, Vol. 50, No. 6, November/December 2014.

17. B. Rajesh and Manjesh "Comparison of Harmonics and THD Suppression with Three and 5 Level Multilevel Inverter-Cascaded H-bridge" IEEE International Conference on Circuit, Power and Computing Technologies [ICCPCT], pp 1-6, 2016.

\section{AUTHORS PROFILE}

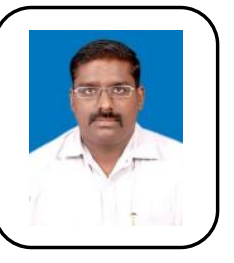

Dr.V.Tamilselvan is Professor in Electrical and Electronics Engineering Department, Karpagam College of Engineering, Coimbatore, India. He received his B.E degree in Electrical and Electronics Engineering and M.E degree and Ph.D in Power Systems. He has more than 15 years of teaching experience and published 21 technical papers in international and national journals/conferences proceedings. He received Rs.4.65lakh from University Grants Commission under the scheme of support for Minor Research Project entitled "An improved method for determining contribution of utility and customer harmonic Distortions in power distribution systems".

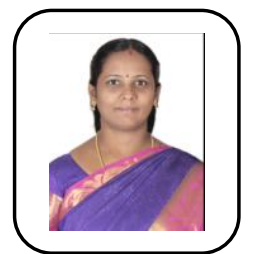

Ms. J.C Vinitha is an Associate Professor in Electrical and Electronics Engineering Department, R.M.D Engineering College, Chennai, India. She received her B.E degree in Electrical \& Electronics Engineering from the Institute of Road and Transport Technology, Erode, India, M.Tech degree in Power Electronics and Drives from SASTRA University, Thanjavur, India and persuing Ph.D under Anna University, Chennai, India.She has more than 14.5 years of teaching experience and published 3 technical papers in International journals. She is a member of IEEE. 
Dr. P.Usha Rani is Professor in Electrical and Electronics Engineering Department, R.M.D Engineering College, Chennai, India. She received her B.E. degree in Electrical \& Electronics Engineering from the Government College of Technology, Coimbatore, India, M.E. degree in Power Systems from College of Engineering, Anna University, Chennai, India and Ph.D in the area of Power Electronics and Drives from Anna University, Chennai, India. She has published over 57 technical papers in international and national journals / conferences proceedings (IEEE Xplore-7). She has $221 \frac{2}{2}$ years of teaching experience. Her earlier industrial experience 4 years was with Chemin Controls, Pondicherry, India. Her research interests on application of power electronics to power quality problems and FACTS. She is a Senior member of IEEE and Life member of Indian Society for Technical Education.

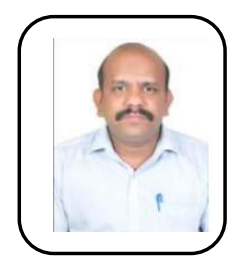

Dr. S. Siva Subramanian is Professor in Electrical and Electronics Engineering Department, Karpagam College of Engineering, Coimbatore, India. He received his B.E. degree in Instrumentation \& Control Engineering and M.Tech. degree in Control Systems and Instrumentation and Ph.D in Instrumentation and Control Systems from Anna University, Chennai. He has more than 15 years of teaching experience and published 21 technical papers in international and national journals / conferences proceedings. He is a life member of ISTE, ISoI and IE(I). 